\title{
Synthesis and Anti-HCV Activity of 3',5'-cyclic SATE Phosphonodiester Nucleoside as a Novel Prodrug
}

\author{
Lian Jin Liu, ${ }^{\dagger}$ Rac Seok Seo, ${ }^{\dagger}$ Seung Won Yoo, ${ }^{\dagger}$ Jin Choi, and Joon Hee Hong ${ }^{*}$ \\ BK21-Project Team, College of Pharmacy, Chosun University, Kwangju 501-759, Korea. *E-mail: hongjh@chosun.ac.kr \\ ${ }^{\dagger}$ KAST PHARM CO., LTD. \#516 Hanyang University, Sa-Dong, Sangnok-Gu, Ansan-Si, Gyeonggi-Do, Korea \\ Received December 22, 2009, Accepted February 10, 2010
}

\begin{abstract}
A novel 2',4'-dimethyl carbocyclic adenosine 5'-phosphonic acid analogue (20) was prepared using acyclic stereoselective route from commercially available 4-hydroxybutan-2-one (4). To improve cellular permeability and enhance the anti-HCV activity of this phosphonic acid, a 3',5'-cyclic SATE phosphonodiester nucleoside prodrug (22) was prepared. The synthesized phosphonic nucleoside analogues, (20) and (22), were assayed for their ability to inhibit HCV RNA replication in a subgenomic replicon Huh7 cell line.
\end{abstract}

Key Words: Anti-HCV agent, Prodrug, Nucleoside phosphonate

\section{Introduction}

Hepatitis $\mathrm{C}$ virus (HCV) is the major causative agent for non$\mathrm{A}$, non-B virally induced hepatitis. ${ }^{1} \mathrm{HCV}$ infections often lead to reduced liver function, cirrhosis and hepatocellular carcinoma and eventually liver transplantation. The current approved therapy based on pegylated interferon alone or in combination with ribavirin is effective in only approximately half of the genotype 1 population. ${ }^{2}$ Moreover, this limited efficacy is often associated with significant side effects, leading to discontinuation of treatment. ${ }^{3}$ Therefore, there is a need for the development of more effective therapeutic agents for the treatment of HCV infection. ${ }^{4}$ HCV RNA-dependent RNA polymerase (NS5B) and NS3/4A protease are currently the most promising targets for the development of novel treatments. The activities of these virally encoded enzymes are essential for HCV replication, and antiviral agents targeting these enzymes are in both preclinical and clinical development. To date, most of the reported nucleoside analogues $^{5}$ that inhibit HCV polymerase have modifications at the $2^{\prime}$ or $4^{\prime}$ position of the sugar. ${ }^{6}$

For example, 2'-methyl ribonucleosides yield compounds with excellent chain-terminating properties. Among them, $2^{\prime}-C$ methylcytidine ${ }^{7}(\mathbf{1})$ and $2^{\prime}-C$-methyladenosine ${ }^{8}(\mathbf{2})$ were discovered as potent anti-HCV agents and $2^{\prime}-C$-methylcytidine is in phase II clinical trials. Furthermore, 4'-bis-SATE (bis-S-acyl2-thioethyl) prodrug of adenine analogue ${ }^{9}(3)$ showed excellent anti-HCV activity in the genotype $1 \mathrm{~b}$ subgenomic replicon system (Figure 1).

Actually, these antiviral nucleoside analogues do not directly exert antiviral activity, but rather are prodrugs of active phosphorylated metabolites that are formed by the actions of various kinases in cells. Ultimately, the triphosphates of these drugs are responsible for their actual antiviral activity by acting as inhibitors of HCV polymerase. ${ }^{10}$

A nucleoside 5'-phosphonate is essentially a nucleoside monophosphate analogue. However, a phosphonate has certain advantages over its phosphate counterpart as it is metabolically stable because its phosphorus-carbon bond is not susceptible
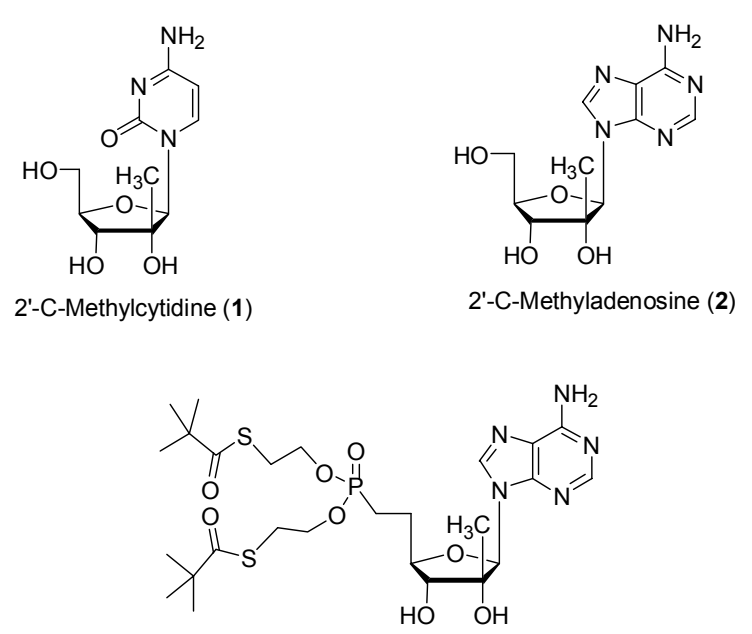

Bis-SATE 2'-C-Methyladenosine (3)

Figure 1. Structure of potent anti-HCV agents.

to hydrolytic cleavage. ${ }^{11}$ Moreover, a phosphonate nucleoside can skip the requisite first phosphorylation, which is a crucial step for the activation of nucleosides. Though triphosphates of several of these nucleoside analogues exhibit excellent RdRp inhibitory potency, only a few nucleoside derivatives have exhibited biological activity in cell culture assays. This might be due to poor cellular penetration coupled with insufficient metabolism of these nucleoside derivatives to 5'-triphosphates.

Stimulated by the finding that branched nucleoside analogues exhibit excellent antiviral activities, we sought to synthesize novel classes of nucleotides comprising 2',4'- $C$-dimethyl carbocyclic 5'-phosphonic acid (20) and its cyclic SATE phosphonodiester prodrug (22) rather than its bis-SATE counterpart which has a bigger molecular size.

The target compounds were prepared from the commercially available starting material (4) as shown in Scheme 1. The alcohol functional group of (4) was temporary masked with $t$-butyldimethylchlorosilane to give ketone derivative (5), which was 


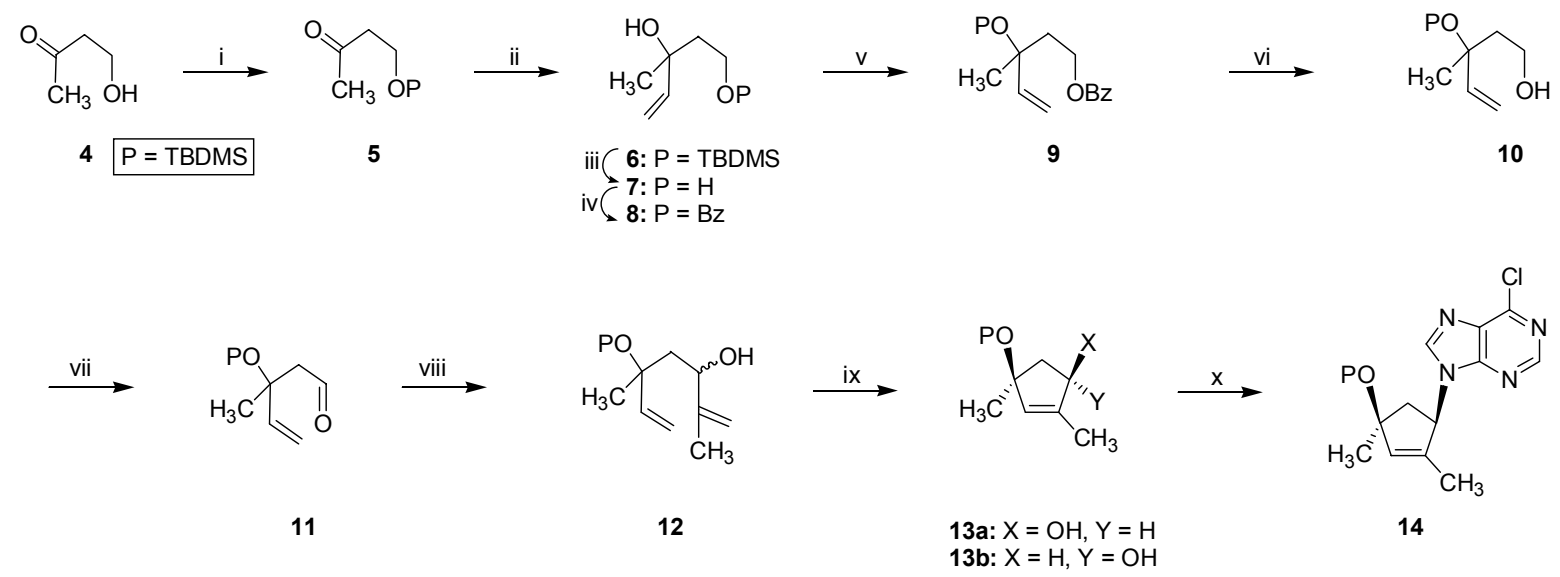

Scheme 1. Synthesis of 6-chloropurine nucleoside intermediate. Reagents: i) TBDMSCl, imidazole, $\mathrm{CH}_{2} \mathrm{Cl}_{2}$; ii) VinylMgBr, THF; iii) TBAF, $\mathrm{THF} / \mathrm{CH}_{3} \mathrm{CN}$; iv) BzCl, DMAP, pyridine; v) TBDMSOTf, DMAP, TEA, $\mathrm{CH}_{2} \mathrm{Cl}_{2}$; vi) $\mathrm{NaOMe}, \mathrm{MeOH}$; vii) $(\mathrm{COCl})_{2}, \mathrm{DMSO}, \mathrm{TEA}_{2} \mathrm{CH}_{2} \mathrm{Cl}$; viii) IsopropenylMgBr, THF; ix) 2nd-Grubbs cat. benzene, reflux; x) 6-chloropurine, $\mathrm{DIAD}, \mathrm{PPh}_{3}$, 1,4-dioxane

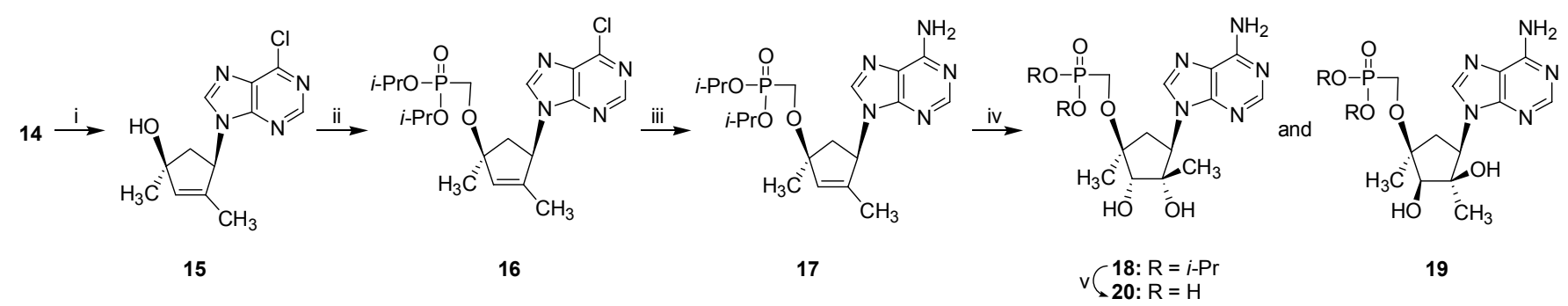

Scheme 2. Synthesis of carbocyclic adenine phosphonic acid (20). Reagents: i) TBAF, THF; ii) $(i-\mathrm{PrO})_{2} \mathrm{POCH}_{2} \mathrm{Br}$, $\mathrm{LiO}-t-\mathrm{Bu}, \mathrm{THF}$; iii) $\mathrm{NH}$, $\mathrm{MeOH}$, steel bomb; iv) $\mathrm{OsO}_{4}, \mathrm{NMO}$, acetone $/ t-\mathrm{BuOH} / \mathrm{H}_{2} \mathrm{O}$; v) $\mathrm{TMSBr}, \mathrm{CH}_{2} \mathrm{Cl}_{2}$

subject to carbonyl addition using vinylmagnesium bromide to yield tertiary alcohol derivative (6). In order to differentiate between the two hydroxyl groups, the silicon protection group of the primary hydroxyl was replaced with a benzoyl group by sequential desilylation and benzoylation to provide $(\mathbf{8})$. Silylation of the tertiary hydroxyl group of (8) was successfully accomplished using trimethylsilyl trifluoromethanesulfonate (TMSOTf) to give fully protected compound (9). The benzoyl protection group of the primary hydroxyl was removed by sodium methoxide $(\mathrm{NaOMe})$ to provide the alcohol derivative (10), which was oxidized to the aldehyde (11) using Swern oxidation conditions (DMSO, oxalyl chloride, TEA). The aldehyde (11) was subjected to nucleophilic Grignard conditions by isopropenylmagnesium bromide $\left[\mathrm{CH}_{2}=\mathrm{C}\left(\mathrm{CH}_{3}\right) \mathrm{MgBr}\right]$ to yield divinyl (12).

Without separation of diastereomeric mixture, divinyl (12) was subjected to ring-closing metathesis (RCM) condition ${ }^{12}$ using 2nd generation Grubbs catalyst to provide cyclopentenol

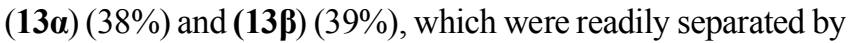
silica gel column chromatography. The relative stereochemical assignments of the two isomers were made readily based on NOE comparisons. Upon irradiation of $C_{1}-\mathrm{H}$, weak NOE patterns were observed at the proximal hydrogens of compound (13b) $\left[C_{4}-\mathrm{CH}_{3}(0.14 \%)\right]$ versus those of compound (13a) $\left[C_{4}\right.$ $\mathrm{CH}_{3}(0.42 \%)$ ] (Figure 2).

To synthesize the desired carbocyclic nucleoside analogues,
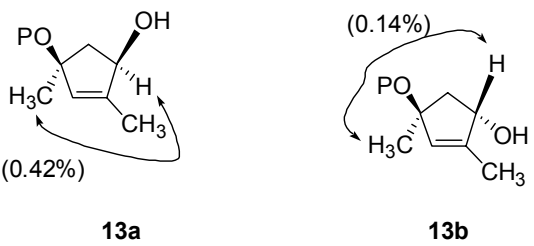

Figure 2. NOE between the proximal hydrogens of 13a and $\mathbf{1 3 b}$.

6-chloropurine was treated with the protected cyclopentenol (13b) in the presence of diisopropylazodicarboxylate (DIAD) and $\mathrm{PPh}_{3}$ to give (14) with a correct configuration. For the synthesis of nucleoside phosphonate by alkylation of the oxygen at $\mathrm{C}_{4}$ of (14), the silyl protection was removed. Further treatment of the nucleoside (15) with diisopropylphosphonomethyl bromide yielded the desired compound (16); the chlorine group of (16) was then transformed to amine with methanolic ammonia in a steel bomb to give adenine derivative (17). The resultant nucleoside phosphonate mimics the overall shape and geometry of a nucleoside monophosphate. Bishydroxylation ${ }^{13}$ of the double bond in (17) was accomplished with a catalytic amount of osmium tetraoxide $\left(\mathrm{OsO}_{4}\right)$ and 4-methyl-morpholine $\mathrm{N}$-oxide (NMO) as the oxidant to give the dihydroxylated (18) as a major reaction product compared to minor isomer (19) (Scheme 2). Their stereochemistries were also readily determined by NOE experiment. These stereochemical outcomes suggest that a bul- 

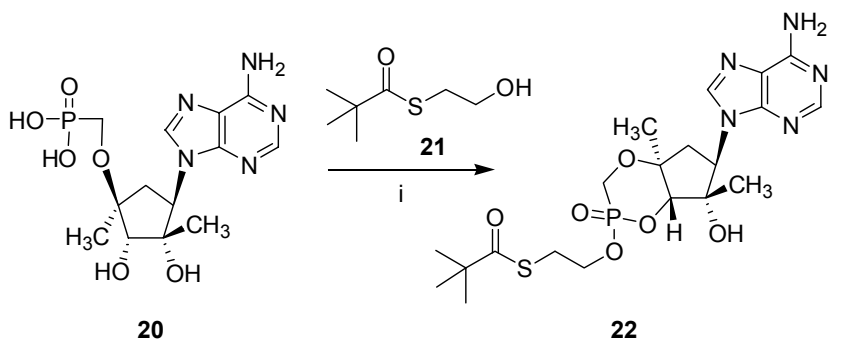

Scheme 3. Synthesis of 3',5'-cyclic-SATE prodrug of adenine analogue Reagents: i) thioester 21, 1-mesitylene-2-sulfonyl-3-nitro-1,2,4-triazole, pyridine

Table 1. Anti-HCV activity of synthesized compounds

\begin{tabular}{ccc}
\hline Compound No. & $\begin{array}{c}\text { Anti-HCV } \\
\mathrm{EC}_{50}(\mu \mathrm{g} / \mathrm{mL})\end{array}$ & $\begin{array}{c}\text { Cytotoxicity } \\
\mathrm{CC}_{50}(\mu \mathrm{g} / \mathrm{mL})\end{array}$ \\
\hline $\mathbf{2 0}$ & 76.9 & $>100$ \\
$\mathbf{2 2}$ & 27.6 & $>100$ \\
$\mathbf{2}-\boldsymbol{C}$-Me-A & 1.9 & $>100$
\end{tabular}

2'-C-Me-A: 2'-C-Methyladenosine. $\mathrm{EC}_{50}(\mu \mathrm{g} / \mathrm{mL})$ : concentration needed to reduce cell replication by $50 \%$. $\mathrm{CC}_{50}(\mu \mathrm{g} / \mathrm{mL})$ : concentration needed to reduce cell viability by $50 \%$

ky group such as the diisopropyl phosphonate group reinforce the steric hindrance of the $\beta$-faces. ${ }^{14}$ Hydrolysis of $(\mathbf{1 8})$ by treatment with bromotrimethylsilane afforded the adenine phosphonic acid (20). To synthesize the thioester-protected analogue, compound (20) was reacted with thioester $(\mathbf{2 1})$ in the presence of 1-mesitylene-2-sulfonyl-3-nitro-1,2,4-triazole (MSNT) ${ }^{15}$ to provide the final prodrug (22) (Scheme 3).

The newly synthesized nucleoside analogues (20) and (22) were assayed for anti-HCV activity using an in vitro assay system that is suitable for monitoring anti-HCV activities of compounds. ${ }^{16}$ This system is composed of a human hepatocarcinoma cell line (Huh-7) supporting multiplication of a HCV replication, and the results are summarized in Table 1 . These cells contain a HCV subgenomic replicon RNA encoding a luciferase reporter gene as a marker. The antiviral potency of the nucleoside analogues against the $\mathrm{HCV}$ replicon is expressed as $\mathrm{EC}_{50}$, which was quantified by a luciferase assay after a two-days incubation period with the tested compound. To confirm the anti-HCV potency of compounds, subgenomic replicon RNA levels were quantified by real-time RT-PCR analysis. In addition, the associated cytotoxicity (expressed as $\mathrm{CC}_{50}$ in Table 1) was evaluated in a tetrazolium (XTT)-based assay. 2'- $C$-methyladenosine was selected as the reference standard due to its structure similarity to the newly synthesized compounds.

The synthesized nucleoside prodrug (22) exhibited encouraging improvement in cell-based activity compared with phosphonic acid (20). A significant step forward in terms of activity could then be made with the introduction of 3',5'-cyclic-SATE protecting group as a prodrug scaffold.

\section{Experimental Section}

Melting points were determined on a Mel-temp II laboratory device and are uncorrected. NMR spectra were recorded on a
JEOL 300 Fourier transform spectrometer (JEOL, Tokyo, Japan); chemical shifts are reported in parts per million $(\delta)$ and signals are reported as s (singlet), d (doublet), t (triplet), q (quartet), m (multiplet) and dd (doublet of doublets). UV spectra were obtained on a Beckman DU-7 spectrophotometer (Beckman, South Pasadena, CA, USA). MS spectra were run in electrospray ionization (ESI) mode. The elemental analyses were performed using a Perkin-Elmer 2400 analyzer (Perkin-Elmer, Norwalk, CT, USA). TLC was performed on Uniplates (silica gel) purchased from Analtech Co. (7558, Newark, DE, USA). All reactions were carried out under an atmosphere of nitrogen unless specified. Dry dichloromethane, benzene and pyridine were obtained by distillation from $\mathrm{CaH}_{2}$. Dry THF was obtained by distillation from $\mathrm{Na}$ and benzophenone immediately prior to use.

4-(t-Butyldimethylsilanyloxy) butan-2-one (5). To a solution of 4-hydroxy-butan-2-one 4 (10.0 g, $113.5 \mathrm{mmol}$ ) and imidazole (11.59 g, $170.24 \mathrm{mmol})$ in $\mathrm{CH}_{2} \mathrm{Cl}_{2}(250 \mathrm{~mL}), \mathrm{TBDMSCl}$ (18.82 g, $124.85 \mathrm{mmol}$ ) was added slowly at $0{ }^{\circ} \mathrm{C}$ and stirred overnight at $\mathrm{rt}$. The reaction solvent was evaporated under reduced pressure. The residue was poured into water $(200 \mathrm{~mL})$ and extracted with ethyl acetate $(200 \mathrm{~mL})$ two times. The combined organic layer was dried over anhydrous $\mathrm{MgSO}_{4}$, filtered, and concentrated under reduced pressure. The residue was purified by silica gel column chromatography (EtOAc/hexane, 1:25) to give compound 5 (21.36 g, 93\%) as a colorless oil: ${ }^{1} \mathrm{H}$ NMR $\left(\mathrm{CDCl}_{3}\right.$, $300 \mathrm{MHz}) \delta 3.91(\mathrm{t}, J=7.0 \mathrm{~Hz}, 2 \mathrm{H}), 2.72(\mathrm{t}, J=7.0 \mathrm{~Hz}, 2 \mathrm{H}), 2.17$ $(\mathrm{s}, 3 \mathrm{H}), 0.81(\mathrm{~s}, 9 \mathrm{H}), 0.01(\mathrm{~s}, 6 \mathrm{H}) ;{ }^{13} \mathrm{C} \mathrm{NMR}\left(\mathrm{CDCl}_{3}\right) \delta 208.6$, $59.3,46.2,25.5,18.7,-5.5$.

( \pm )-5-(t-Butyldimethylsilanyloxy)-3-methylpent-1-en-3-ol (6). To a solution of $5(5.4 \mathrm{~g}, 26.68 \mathrm{mmol})$ in dry THF $(50 \mathrm{~mL})$ was slowly added vinylMgBr $(32.79 \mathrm{~mL}, 1.0 \mathrm{M}$ solution in THF) at $-78^{\circ} \mathrm{C}$. After $5 \mathrm{~h}$, saturated $\mathrm{NH}_{4} \mathrm{Cl}$ solution $(32 \mathrm{~mL})$ and water $(100 \mathrm{~mL})$ were sequentially added to the mixture, and the reaction mixture was slowly warmed to rt. The mixture was extracted with EtOAc $(100 \mathrm{~mL})$ two times. The combined organic layer was dried over $\mathrm{MgSO}_{4}$, filtered, and evaporated. The residue was purified by silica gel column chromatography (EtOAc/ hexane, $1: 15)$ to give $6(4.92 \mathrm{~g}, 80 \%)$ as a colorless oil: ${ }^{1} \mathrm{H}$ NMR $\left(\mathrm{CDCl}_{3}, 300 \mathrm{MHz}\right) \delta 5.78(\mathrm{dd}, J=17.4,10.8 \mathrm{~Hz}, 1 \mathrm{H}), 5.28(\mathrm{~d}$, $J=17.3 \mathrm{~Hz}, 1 \mathrm{H}), 5.04$ (d, $J=10.8 \mathrm{~Hz}, 1 \mathrm{H}), 3.81-3.69$ (m, 2H), $1.85-1.76(\mathrm{~m}, 1 \mathrm{H}), 1.59-1.53(\mathrm{~m}, 1 \mathrm{H}), 1.18(\mathrm{~s}, 3 \mathrm{H}), 0.83(\mathrm{~s}, 9 \mathrm{H})$, $0.02(\mathrm{~m}, 6 \mathrm{H}) ;{ }^{13} \mathrm{C} \mathrm{NMR}\left(\mathrm{CDCl}_{3}\right) \delta 144.3,112.2,73.75,61.0$, 41.6, 28.6, 25.7, 18.2, -5.5; Analysis for $\mathrm{C}_{12} \mathrm{H}_{26} \mathrm{O}_{2} \mathrm{Si}$, Calcd.: $\mathrm{C}$, 62.55; H, 11.37; Found: C, 62.47; H, 11.31 .

( \pm -3-Methylpent-4-ene-1,3-diol (7). TBAF (7.8 mL, 1.0 M solution in THF) was added to a solution of $6(1.5 \mathrm{~g}, 6.51 \mathrm{mmol})$ in cosolvent $\left(10 \mathrm{~mL}, \mathrm{THF} / \mathrm{CH}_{3} \mathrm{CN} 1: 1 \mathrm{v} / \mathrm{v}\right)$ at $0{ }^{\circ} \mathrm{C}$. The mixture was stirred overnight at room temperature and concentrated. The residue was purified by silica gel column chromatography $\left(\mathrm{MeOH} / \mathrm{CH}_{2} \mathrm{Cl}_{2}, 1: 7\right)$ to give 7 (635 mg, 84\%): ${ }^{1} \mathrm{H}$ NMR $\left(\mathrm{DMSO}-d_{6}, 300 \mathrm{MHz}\right) \delta 5.92(\mathrm{dd}, J=17.4,11.1 \mathrm{~Hz}, 1 \mathrm{H}), 5.34$ $(\mathrm{d}, J=17.3 \mathrm{~Hz}, 1 \mathrm{H}), 5.14$ (d, $J=11.2 \mathrm{~Hz}, 1 \mathrm{H}), 5.09$ (s, 1H), $4.88(\mathrm{t}, J=4.8 \mathrm{~Hz}, 1 \mathrm{H}), 3.84(\mathrm{br} \mathrm{s}, 2 \mathrm{H}), 1.88(\mathrm{~m}, 1 \mathrm{H}), 1.71(\mathrm{~m}$, $3 \mathrm{H}) ;{ }^{13} \mathrm{C} \mathrm{NMR}\left(\mathrm{DMSO}-d_{6}\right) \delta 144.3,112.3,74.4,60.1,42.1,28.8$; Analysis for $\mathrm{C}_{6} \mathrm{H}_{12} \mathrm{O}_{2}$, Calcd.: C, 62.04; H, 10.41; Found: C, 61.96; H, 10.44 .

( \pm )-Benzoic acid 3-hydroxy-3-methylpent-4-enyl ester(8). To a solution of $7(2.5 \mathrm{~g}, 21.52 \mathrm{mmol})$ in anhydrous pyridine 
(25 mL) was added benzoyl chloride (3.66 g, $23.67 \mathrm{mmol}$ ) and dimethylamino pyridine (DMAP) $(525 \mathrm{mg}, 4.3 \mathrm{mmol})$ at $0{ }^{\circ} \mathrm{C}$. The reaction mixture was stirred overnight at $\mathrm{rt}$. The reaction mixture was quenched with saturated $\mathrm{NaHCO}_{3}$ solution (10 $\mathrm{mL}$ ), stirred for 20 minutes and concentrated under reduced pressure. The residue was poured into water $(100 \mathrm{~mL})$ and extracted with EtOAc $(100 \mathrm{~mL})$ twice. The combined organic layer was washed with brine, dried over $\mathrm{MgSO}_{4}$, filtered, and concentrated. The residue was purified by silica gel column chromatography (EtOAc/hexane, 1:10) to give $\mathbf{8}(3.46 \mathrm{~g}, 73 \%)$ as a colorless syrup: ${ }^{1} \mathrm{H} \mathrm{NMR}\left(\mathrm{CDCl}_{3}, 300 \mathrm{MHz}\right) \delta 8.03(\mathrm{~m}, 2 \mathrm{H}), 7.57(\mathrm{~m}$, $1 \mathrm{H}), 7.45(\mathrm{~m}, 2 \mathrm{H}), 5.95(\mathrm{dd}, J=17.4,10.8 \mathrm{~Hz}, 1 \mathrm{H}), 5.25(\mathrm{~d}, J=$ $17.4 \mathrm{~Hz}, 1 \mathrm{H}), 5.07(\mathrm{~d}, J=10.8 \mathrm{~Hz}, 1 \mathrm{H}), 4.50-4.40(\mathrm{~m}, 2 \mathrm{H})$, 2.10-1.99 (m, 2H), $1.37(\mathrm{~s}, 3 \mathrm{H}) ;{ }^{13} \mathrm{C} \mathrm{NMR}\left(\mathrm{CDCl}_{3}\right) \delta 166.5$, 144.2, 132.9, 130.1, 129.5, 128.3, 112.3, 72.3, 61.6, 40.3, 28.5; Analysis for $\mathrm{C}_{13} \mathrm{H}_{16} \mathrm{O}_{3}$, Calcd.: C, 70.89; H, 7.32; Found: C, 70.92; H, 7.36.

( \pm -Benzoic acid 3-(t-butyldimethylsilanyloxy)-3-methylpent-4-enyl ester (9). To a solution of 8 (2.2 g, $9.99 \mathrm{mmol})$ in anhydrous $\mathrm{CH}_{2} \mathrm{Cl}_{2}(20 \mathrm{~mL})$ was added TEA (2.02 g, 19.98 mmol) and DMAP (262 mg, $2.15 \mathrm{mmol}$ ) at $0{ }^{\circ} \mathrm{C}$. $t$-Butyldimethylsilyl trifluomethanesulfonate (TBDMSOTf) (2.9 g, 10.99 mmol) was added to this mixture and the reaction mixture was stirred overnight at $\mathrm{rt}$ and quenched with cold $\mathrm{H}_{2} \mathrm{O}(10 \mathrm{~mL})$. The mixture was diluted with water $(100 \mathrm{~mL})$ and extracted with EtOAc $(80 \mathrm{~mL})$ two times. Combined organic layer was washed with brine, dried over $\mathrm{MgSO}_{4}$, filtered, and concentrated. The residue was purified by silica gel column chromatography (EtOAc/hexane, 1:25) to give $\mathbf{9}(2.7 \mathrm{~g}, 81 \%)$ as colorless syrup: ${ }^{1} \mathrm{H} \mathrm{NMR}\left(\mathrm{CDCl}_{3}, 300 \mathrm{MHz}\right) \delta 7.93(\mathrm{~m}, 2 \mathrm{H}), 7.45(\mathrm{~m}, 1 \mathrm{H}), 7.32$ $(\mathrm{m}, 2 \mathrm{H}), 5.81(\mathrm{dd}, J=17.3,10.8 \mathrm{~Hz}, 1 \mathrm{H}), 5.14(\mathrm{~d}, J=17.2 \mathrm{~Hz}$, $1 \mathrm{H}), 4.93(\mathrm{~d}, J=10.8 \mathrm{~Hz}, 1 \mathrm{H}), 4.36-4.30(\mathrm{~m}, 2 \mathrm{H}), 1.95-1.87(\mathrm{~m}$, $2 \mathrm{H}), 1.31(\mathrm{~s}, 3 \mathrm{H}), 0.81(\mathrm{~s}, 9 \mathrm{H}), 0.02(\mathrm{~s}, 6 \mathrm{H}) ;{ }^{13} \mathrm{CNMR}\left(\mathrm{CDCl}_{3}\right)$ $\delta 166.5,144.8,132.7,130.4,129.5,128.2,112.2,74.4,61.8$, 42.1, 27.8, 25.8, 18.2, -5.56; Analysis for $\mathrm{C}_{19} \mathrm{H}_{30} \mathrm{O}_{3} \mathrm{Si}$, Calcd.: C, 68.22; H, 9.04; Found: C, 68.27; H, 8.97.

( \pm )-3-( $t$-Butyldimethylsilanyloxy)-3-methylpent-4-en-1-ol (10). To a solution of 9 (1.6 g, $4.78 \mathrm{mmol})$ in $\mathrm{MeOH}(12 \mathrm{~mL})$ was added $\mathrm{NaOMe}(1.43 \mathrm{~mL}, 1.0 \mathrm{M}$ in $\mathrm{MeOH})$ at $0{ }^{\circ} \mathrm{C}$. The reaction mixture was stirred overnight at $\mathrm{rt}$ and concentrated. The residue was purified by silica gel column chromatography (EtOAc/hexane, 1:10) to give $\mathbf{1 0}(991 \mathrm{mg}, 90 \%)$ as a colorless syrup: ${ }^{1} \mathrm{H} \mathrm{NMR}\left(\mathrm{CDCl}_{3}, 300 \mathrm{MHz}\right) \delta 5.91(\mathrm{dd}, J=17.3,10.7 \mathrm{~Hz}$, $1 \mathrm{H}), 5.20(\mathrm{~d}, J=17.3 \mathrm{~Hz}, 1 \mathrm{H}), 5.04(\mathrm{~d}, J=10.8 \mathrm{~Hz}, 1 \mathrm{H}), 4.41-$ $4.36(\mathrm{~m}, 2 \mathrm{H}), 2.08-1.99(\mathrm{~m}, 2 \mathrm{H}), 1.32(\mathrm{~s}, 3 \mathrm{H}) ;{ }^{13} \mathrm{CNMR}\left(\mathrm{CDCl}_{3}\right)$ $\delta$ 144.4 $112.3,71.7,61.3,42.5,28.9,25.6,18.4,-5.6$; Analysis for $\mathrm{C}_{12} \mathrm{H}_{26} \mathrm{O}_{2} \mathrm{Si}$, Calcd.: C, 62.55; H, 11.37; Found: C, 62.47; H, 11.31 .

3-(t-Butyldimethylsilanyloxy)-3-methylpent-4-enal (11). To a stirred solution of oxalyl chloride $(0.072 \mathrm{~mL}, 0.816 \mathrm{mmol})$ in $\mathrm{CH}_{2} \mathrm{Cl}_{2}(8 \mathrm{~mL})$ was added a solution of DMSO $(0.072 \mathrm{~mL}$, $1.08 \mathrm{mmol})$ in $\mathrm{CH}_{2} \mathrm{Cl}_{2}(0.8 \mathrm{~mL})$ dropwise at $-78^{\circ} \mathrm{C}$. The resulting solution was stirred at $-78^{\circ} \mathrm{C}$ for $5 \mathrm{~min}$, and a solution of alcohol 10 (197 mg, $0.454 \mathrm{mmol}$ ) in $\mathrm{CH}_{2} \mathrm{Cl}_{2}(3 \mathrm{~mL})$ was added dropwise. The mixture was stirred at $-78^{\circ} \mathrm{C}$ for $20 \mathrm{~min}$ and TEA $(0.32 \mathrm{~mL}, 2.26 \mathrm{mmol})$ was added. The resulting mixture was warmed to $0{ }^{\circ} \mathrm{C}$ and stirred for $30 \mathrm{~min} . \mathrm{H}_{2} \mathrm{O}(6 \mathrm{~mL})$ was added, and the solution was stirred at room temperature for $20 \mathrm{~min}$. The mixture was diluted with water $(50 \mathrm{~mL})$ and then extracted with EtOAc $(40 \mathrm{~mL})$ two times. The combined organic layer was dried over $\mathrm{MgSO}_{4}$ and filtered. The filtrate was concentrated under reduced pressure and the residue was purified by silica gel column chromatography (EtOAc/hexane, 1:30) to give aldehyde compound 11 (193 mg, 99\%) as a colorless oil: ${ }^{1} \mathrm{H} \mathrm{NMR}\left(\mathrm{CDCl}_{3}\right.$, $300 \mathrm{MHz}) \delta 9.94(\mathrm{~s}, 1 \mathrm{H}), 5.92(\mathrm{dd}, J=17.3,10.7 \mathrm{~Hz}, 1 \mathrm{H}), 5.13$ $(\mathrm{d}, J=17.2 \mathrm{~Hz}, 1 \mathrm{H}), 5.00(\mathrm{~d}, J=10.7 \mathrm{~Hz}, 1 \mathrm{H}), 2.63-2.57$ (m, $2 \mathrm{H}), 1.35(\mathrm{~s}, 3 \mathrm{H}) ;{ }^{13} \mathrm{C} \mathrm{NMR}\left(\mathrm{CDCl}_{3}\right) \delta 201.3,144.8,112.6,61.9$, $58.6,28.8,25.7,18.6,-5.4$.

(rel)-(3R and $3 S, 5 S)-5-(t$-Butyldimethylsilanyloxy)-2,5-dimethylhepta-1,6-dien-3-ol (12). To a solution of 11 (2.5 g, 10.95 $\mathrm{mmol})$ in dry THF $(20 \mathrm{~mL})$ was slowly added isopropenylMgBr (13.13 mL, $1.0 \mathrm{M}$ solution in THF) at $-20^{\circ} \mathrm{C}$ and stirred $5 \mathrm{~h}$ at the same temperature. Saturated $\mathrm{NH}_{4} \mathrm{Cl}$ solution $(13 \mathrm{~mL})$ and water $(70 \mathrm{~mL})$ were sequentially added to the mixture, which was slowly warmed to rt and extracted with EtOAc $(70 \mathrm{~mL})$ two times. The combined organic layer was dried over $\mathrm{MgSO}_{4}$, filtered, and evaporated. The residue was purified by silica gel column chromatography (EtOAc/hexane, 20) to give $12(2.39 \mathrm{~g}, 81 \%)$ as diastereomeric mixture: ${ }^{1} \mathrm{H}$ NMR $\left(\mathrm{CDCl}_{3}, 300 \mathrm{MHz}\right) \delta 6.01(\mathrm{dd}$, $J=17.4,10.8 \mathrm{~Hz}, 1 \mathrm{H}), 5.13(\mathrm{~d}, J=17.2 \mathrm{~Hz}, 1 \mathrm{H}), 5.26-5.00$ (m, $4 \mathrm{H}), 3.82-3.87(\mathrm{~m}, 1 \mathrm{H}), 1.87-1.55(\mathrm{~m}, 2 \mathrm{H}), 1.45(\mathrm{~s}, 3 \mathrm{H}), 1.34(\mathrm{~s}$, $3 \mathrm{H}) ;{ }^{13} \mathrm{C} \mathrm{NMR}\left(\mathrm{CDCl}_{3}\right) \delta 147.2,145.9,143.4,113.3,112.3$, $110.0,109.9,78.0,72.5,72.4,48.6,48.3,29.0,25.8,18.1,-5.5$.

(rel)-(1S and 4S)-4-( $t$-Butyldimethylsilanyloxy)-2,4-dimethylcyclopent-2-enol (13a) and (rel)-(1R and 4S)-4-( $t$-butyldimethylsilanyloxy)-2,4-dimethylcyclopent-2-enol (13b). To a solution of 12 ( $1.16 \mathrm{~g}, 4.3 \mathrm{mmol})$ in dry benzene $(6 \mathrm{~mL})$ was added $2^{\text {nd }}$ generation Grubbs catalyst $(63.5 \mathrm{mg} 0.075 \mathrm{mmol})$. The reaction mixture was refluxed overnight and cooled to room temperature. The mixture was concentrated in vacuum, and the residue was purified by silica gel column chromatography (EtOAc/hexane, 1:10) to give cyclopentenol 13a(354 mg, 34\%) and 13b (344 mg, 33\%) as colorless oils, respectively. Cyclopentenol 13a: ${ }^{1} \mathrm{H} \mathrm{NMR}\left(\mathrm{CDCl}_{3}, 300 \mathrm{MHz}\right) \delta 5.40(\mathrm{~s}, 1 \mathrm{H}), 4.21$ (dd, $J=6.6,1.8 \mathrm{~Hz}, 1 \mathrm{H}), 2.17(\mathrm{dd}, J=12.6,8.8 \mathrm{~Hz}, 1 \mathrm{H}), 1.99$ (dd, $J=12.6,6.6 \mathrm{~Hz}, 1 \mathrm{H}), 1.72(\mathrm{~s}, 3 \mathrm{H}), 1.51(\mathrm{~s}, 3 \mathrm{H}), 0.82(\mathrm{~s}, 9 \mathrm{H})$, $0.01(\mathrm{~s}, 6 \mathrm{H}) ;{ }^{13} \mathrm{C} \mathrm{NMR}\left(\mathrm{CDCl}_{3}\right) \delta 139.6,125.8,73.2,70.1,45.7$, 29.3, 25.6, 18.7, 16.7, -5.5; Analysis for $\mathrm{C}_{13} \mathrm{H}_{26} \mathrm{O}_{2} \mathrm{Si}$, Calcd.: $\mathrm{C}$, 64.41; H, 10.81; Found: C, 64.36; H, 10.80; Cyclopentenol 13b: ${ }^{1} \mathrm{H} \mathrm{NMR}\left(\mathrm{CDCl}_{3}, 300 \mathrm{MHz}\right) \delta 5.41(\mathrm{~s}, 1 \mathrm{H}), 4.19(\mathrm{~d}, J=7.8 \mathrm{~Hz}$, $1 \mathrm{H}), 2.19(\mathrm{dd}, J=12.2,8.4 \mathrm{~Hz}, 1 \mathrm{H}), 2.04(\mathrm{dd}, J=12.3,7.8 \mathrm{~Hz}$, 1H), $1.74(\mathrm{~s}, 3 \mathrm{H}), 1.50(\mathrm{~s}, 3 \mathrm{H}), 0.83(\mathrm{~s}, 9 \mathrm{H}), 0.02(\mathrm{~s}, 6 \mathrm{H}) ;{ }^{13} \mathrm{C}$ $\mathrm{NMR}\left(\mathrm{CDCl}_{3}\right) \delta 138.9,124.3,73.8,69.9,44.2,29.6,25.5,18.6$, 15.8, -5.6; Analysis for $\mathrm{C}_{13} \mathrm{H}_{26} \mathrm{O}_{2} \mathrm{Si}$, Calcd.: C, 64.41; H, 10.81; Found: $\mathrm{C}, 64.43 ; \mathrm{H}, 10.85$.

(rel)-(1'R,4'S)-9-[4-(t-Butyldimethylsilyloxy)-2,4-dimethylcyclopent-2-en-1-yl] 6-chloropurine (14). To a solution containing compound $\mathbf{1 3 b}(263 \mathrm{mg}, 1.085 \mathrm{mmol})$, triphenylphosphine (570 mg, $2.17 \mathrm{mmol}$ ) and 6-chloropurine (335 mg, $2.17 \mathrm{mmol})$ in anhydrous 1,4-dioxane $(10 \mathrm{~mL})$, diisopropyl azodicarboxylate (DIAD) $(438 \mathrm{mg}, 2.17 \mathrm{mmol})$ was added dropwise at $-20{ }^{\circ} \mathrm{C}$ for $30 \mathrm{~min}$. under nitrogen. The reaction mixture was stirred for $5 \mathrm{~h}$ at $0{ }^{\circ} \mathrm{C}$ under nitrogen. The solvent was concentrated under reduced pressure and the residue was purified by silica gel column chromatography (EtOAc/hexane, 2:1) to give compound 14 (189 mg, 46\%): ${ }^{1} \mathrm{H} \mathrm{NMR}\left(\mathrm{CDCl}_{3}, 300 \mathrm{MHz}\right) \delta 8.71$ 
(s, 1H), $8.52(\mathrm{~s}, 1 \mathrm{H}), 5.40(\mathrm{~s}, 1 \mathrm{H}), 4.52(\mathrm{dd}, J=7.8,1.4 \mathrm{~Hz}, 1 \mathrm{H})$, $2.54(\mathrm{dd}, J=12.8,8.8 \mathrm{~Hz}, 1 \mathrm{H}), 2.10(\mathrm{dd}, J=12.9,7.8 \mathrm{~Hz}, 1 \mathrm{H})$, $1.72(\mathrm{~s}, 3 \mathrm{H}), 1.53(\mathrm{~s}, 3 \mathrm{H}), 0.82(\mathrm{~s}, 9 \mathrm{H}), 0.01(\mathrm{~s}, 6 \mathrm{H}) ;{ }^{13} \mathrm{C} \mathrm{NMR}$ $\left(\mathrm{CDCl}_{3}\right) \delta 152.0,151.4,150.9,146.0,139.4,134.1,131.1,71.3$, 58.5, 41.6, 28.9, 25.5, 18.8, 17.8, -5.4; Analysis for $\mathrm{C}_{18} \mathrm{H}_{27^{-}}$ $\mathrm{ClN}_{4} \mathrm{OSi}$, Calcd.: C, 57.05; H, 7.18; N, 14.78; Found: C, 56.96; $\mathrm{H}, 7.11 ; \mathrm{N}, 14.81$.

(rel)-(1'R,4'S)-9-[4-Hydroxy-2,4-dimethylcyclopent-2-en1-yl] 6-chloropurine (15). TBAF $(0.444 \mathrm{~mL}, 1.0 \mathrm{M}$ solution in THF) was added to a solution of $\mathbf{1 4}(140 \mathrm{mg}, 0.37 \mathrm{mmol})$ in THF $(6.0 \mathrm{~mL})$ at $0{ }^{\circ} \mathrm{C}$. The mixture was stirred overnight at room temperature and concentrated. The residue was purified by silica gel column chromatography $(\mathrm{MeOH} / \mathrm{Hexane} / \mathrm{EtOAc}, 0.1: 3: 1)$ to give $15(85 \mathrm{mg}, 87 \%)$ as a white solid: $\mathrm{mp} 160-162{ }^{\circ} \mathrm{C} ;{ }^{1} \mathrm{H}$ $\mathrm{NMR}\left(\mathrm{CDCl}_{3}, 300 \mathrm{MHz}\right) \delta 8.72(\mathrm{~s}, 1 \mathrm{H}), 8.53(\mathrm{~s}, 1 \mathrm{H}), 5.42(\mathrm{~s}$, $1 \mathrm{H}), 4.50(\mathrm{dd}, J=7.6,1.6 \mathrm{~Hz}, 1 \mathrm{H}), 2.59(\mathrm{dd}, J=12.7,8.8 \mathrm{~Hz}$, $1 \mathrm{H}), 2.12(\mathrm{dd}, J=12.8,7.6 \mathrm{~Hz}, 1 \mathrm{H}), 1.73(\mathrm{~s}, 3 \mathrm{H}), 1.49(\mathrm{~s}, 3 \mathrm{H})$; ${ }^{13} \mathrm{C} \mathrm{NMR}\left(\mathrm{CDCl}_{3}\right) \delta 152.3,151.3,150.5,146.2,138.2,133.6$, 131.4, 71.8, 58.2, 40.9, 29.0, 17.9; Analysis for $\mathrm{C}_{12} \mathrm{H}_{13} \mathrm{ClN}_{4} \mathrm{O}$, Calcd.: C, 54.45; H, 4.95; N, 21.17; Found: C, 54.38; H, 5.00; $\mathrm{N}, 21.13$.

(rel)-(1'R,4'S)-Diisopropyl [9-(4-hydroxy-2,4-dimethylcyclopent-2-en-1-yl)] 6-chloropurine] methylphosphonate (16). Both $\mathrm{LiO} t-\mathrm{Bu}$ (7.6 $\mathrm{mL}$ of $1.0 \mathrm{M}$ solution in THF, $7.6 \mathrm{mmol})$ and a solution of diisopropyl bromomethylphosphonate (1.665 g, $6.42 \mathrm{mmol}$ ) in $5 \mathrm{~mL}$ of THF were slowly added to a solution of the cyclopentene nucleoside analogue 15 (1.25 g, $4.74 \mathrm{mmol})$ in $5 \mathrm{~mL}$ of THF at $0{ }^{\circ} \mathrm{C}$ and stirred for $3 \mathrm{~h}$ at $\mathrm{rt}$ under anhydrous conditions. The mixture was quenched by adding water $(10 \mathrm{~mL})$ and further diluted with additional $\mathrm{H}_{2} \mathrm{O}(60 \mathrm{~mL})$. The aqueous layer was extracted with EtOAc $(3 \times 70 \mathrm{~mL})$. The combined organic layer were washed with brine, dried over $\mathrm{MgSO}_{4}$, and concentrated in vacuo. The residue was purified by silica gel column chromatography $(\mathrm{MeOH} / \mathrm{Hexane} / \mathrm{EtOAc}, 0.1: 4: 1)$ to give 16 $(1.34 \mathrm{~g}, 64 \%)$ as a foamy syrup: ${ }^{1} \mathrm{H} \mathrm{NMR}\left(\mathrm{CDCl}_{3}, 300 \mathrm{MHz}\right) \delta$ $8.73(\mathrm{~s}, 1 \mathrm{H}), 8.52(\mathrm{~s}, 1 \mathrm{H}), 5.45(\mathrm{~s}, 1 \mathrm{H}), 4.71(\mathrm{~m}, 2 \mathrm{H}), 4.47(\mathrm{~d}$, $J=7.8 \mathrm{~Hz}, 1 \mathrm{H}), 3.72(\mathrm{~d}, J=8.0 \mathrm{~Hz}, 2 \mathrm{H}), 2.57(\mathrm{dd}, J=12.8,8.8$ $\mathrm{Hz}, 1 \mathrm{H}), 2.16(\mathrm{dd}, J=12.8,7.4 \mathrm{~Hz}, 1 \mathrm{H}), 1.75(\mathrm{~s}, 3 \mathrm{H}), 1.50(\mathrm{~s}$, $3 \mathrm{H}), 1.34(\mathrm{~m}, 12 \mathrm{H}) ;{ }^{13} \mathrm{C} \mathrm{NMR}\left(\mathrm{CDCl}_{3}\right) \delta 152.4,151.3,150.4$, 146.6, 138.6, 133.2, 131.1, 72.2, 70.7, 65.6, 58.2, 41.3, 28.9, 23.7, 17.5; Analysis for $\mathrm{C}_{19} \mathrm{H}_{28} \mathrm{ClN}_{4} \mathrm{O}_{4} \mathrm{P}$, Calcd.: C, 51.53; H, 6.37 ; N, 12.65; Found: C, 51.47; H, 6.40; N, 12.71 .

(rel)-(1'R,4'S)-Diisopropyl [9-(4-hydroxy-2,4-dimethylcyclopent-2-en-1-yl)] adenine] methylphosphonate (17). A solution of $16(150 \mathrm{mg}, 0.34 \mathrm{mmol})$ in saturated methanolic ammonia $(7 \mathrm{~mL})$ was stirred on a steel bomb at $80^{\circ} \mathrm{C}$ for $12 \mathrm{~h}$, and the volatile components were evaporated. The residue was purified by silica gel column chromatography $\left(\mathrm{MeOH} / \mathrm{CH}_{2} \mathrm{Cl}_{2}\right.$, 1:7) to give 17 (86 mg, 60\%) as a solid: $\mathrm{mp} 134-136{ }^{\circ} \mathrm{C} ;{ }^{1} \mathrm{H}$ NMR (DMSO- $\left.d_{6}, 300 \mathrm{MHz}\right) \delta 8.26(\mathrm{~s}, 1 \mathrm{H}), 8.15(\mathrm{~s}, 1 \mathrm{H}), 5.46$ $(\mathrm{s}, 1 \mathrm{H}), 4.71(\mathrm{~m}, 2 \mathrm{H}), 4.48(\mathrm{dd}, J=7.6,1.4 \mathrm{~Hz}, 1 \mathrm{H}), 3.71(\mathrm{~d}, J=$ $8.0 \mathrm{~Hz}, 2 \mathrm{H}), 2.55(\mathrm{dd}, J=12.6,8.7 \mathrm{~Hz}, 1 \mathrm{H}), 2.17(\mathrm{dd}, J=12.6$, $7.5 \mathrm{~Hz}, 1 \mathrm{H}), 1.79(\mathrm{~s}, 3 \mathrm{H}), 1.51(\mathrm{~s}, 3 \mathrm{H}), 1.35(\mathrm{~m}, 12 \mathrm{H}) ;{ }^{13} \mathrm{C} \mathrm{NMR}$ $\left(\mathrm{DMSO}-d_{6}\right) \delta 155.4,152.4,150.7,146.6,138.1,133.7,119.4$, 72.6, 70.2, 65.4, 59.6, 40.8, 29.1, 23.8, 17.3; Analysis for $\mathrm{C}_{19}$ $\mathrm{H}_{30} \mathrm{~N}_{5} \mathrm{O}_{4} \mathrm{P}$, Calcd.: C, 53.89; H, 7.14; N, 16.54; Found: C, 53.85; $\mathrm{H}, 7.16$; N, 16.47.

(rel)-(1'R, 2'S,3'S,4'S)-Diisopropyl [9-(2,3,4-trihydroxy-2,4- dimethylcyclopentyl)] adenine] methylphosphonate (18) and (rel)-(1'R,2'R,3'R,4'S)-diisopropyl [9-(2,3,4-trihydroxy-2,4-dimethylcyclopentyl)] adenine] methylphosphonate (19). Compound 17 (338 $\mathrm{mg}, 0.8 \mathrm{mmol}$ ) was dissolved in a mixture of acetone $(12 \mathrm{~mL}), t-\mathrm{BuOH}(2 \mathrm{~mL})$ and $\mathrm{H}_{2} \mathrm{O}(2 \mathrm{~mL})$ along with 4methylmorpholine $N$-oxide ( $140 \mathrm{mg}, 1.2 \mathrm{mmol}$ ). Subsequently, $\mathrm{OsO}_{4}\left(0.254 \mathrm{~mL}, 0.04 \mathrm{mmol}, 4 \%\right.$ wt $\%$ in $\left.\mathrm{H}_{2} \mathrm{O}\right)$ was added. The mixture was stirred overnight at $\mathrm{rt}$ and quenched with saturated $\mathrm{Na}_{2} \mathrm{SO}_{3}$ solution $(4 \mathrm{~mL})$. The resulting solid was removed by filtration through a pad of Celite, and filtrate was concentrated under reduced pressure. The residue was purified by silica gel column chromatography $\left(\mathrm{MeOH} / \mathrm{CH}_{2} \mathrm{Cl}_{2}, 1: 5\right)$ to give $\mathbf{1 8}$ (139 $\mathrm{mg}, 38 \%$ ) and 19 (51 mg, 14\%): Spectroscopical data for 18: $\mathrm{mp}$ 121-123 ${ }^{\circ} \mathrm{C}$; UV $\left(\mathrm{H}_{2} \mathrm{O}\right) \lambda_{\max } 260.5 \mathrm{~nm} ;{ }^{1} \mathrm{H}$ NMR (DMSO- $d_{6}, 300$ MHz) $\delta 8.30(\mathrm{~s}, 1 \mathrm{H}), 8.14(\mathrm{~s}, 1 \mathrm{H}), 7.17(\mathrm{br} \mathrm{s}, 2 \mathrm{H}), 5.11(\mathrm{~s}, 1 \mathrm{H})$, $4.83(\mathrm{~d}, J=4.6 \mathrm{~Hz}, 1 \mathrm{H}), 4.70(\mathrm{~m}, 2 \mathrm{H}), 3.86(\mathrm{dd}, J=7.6,1.6 \mathrm{~Hz}$, $1 \mathrm{H}), 3.71(\mathrm{~d}, J=8.1 \mathrm{~Hz}, 2 \mathrm{H}), 3.61(\mathrm{~s}, 1 \mathrm{H}), 2.16(\mathrm{dd}, J=12.8,8.8$ $\mathrm{Hz}, 1 \mathrm{H}), 1.97$ (dd, $J=12.7,7.6 \mathrm{~Hz}, 1 \mathrm{H}), 1.36(\mathrm{~m}, 15 \mathrm{H}), 1.31$ (s, $3 \mathrm{H}) ;{ }^{13} \mathrm{C}$ NMR (DMSO- $\left.d_{6}\right) \delta 155.6,152.3,150.1,145.9,120.3$, 89.8, 73.0, 70.5, 69.1 , 65.7, 54.2 , 29.4, 23.3, 19.3, 16.2; Analysis for $\mathrm{C}_{19} \mathrm{H}_{32} \mathrm{~N}_{5} \mathrm{O}_{6} \mathrm{P}$, Calcd.: C, 49.88; H, 7.05; N, 15.31; Found: C, 49.92; H, 6.98; N, 15.27; Spectroscopical data for 19: mp 117$119{ }^{\circ} \mathrm{C}$; UV $\left(\mathrm{H}_{2} \mathrm{O}\right) \lambda_{\max } 261.5 \mathrm{~nm} ;{ }^{1} \mathrm{H}$ NMR (DMSO- $d_{6}, 300$ $\mathrm{MHz}) \delta 8.33(\mathrm{~s}, 1 \mathrm{H}), 8.16(\mathrm{~s}, 1 \mathrm{H}), 7.18$ (br s, 2H), $5.13(\mathrm{~s}, 1 \mathrm{H})$, 4.85 (br s, 1H), $4.71(\mathrm{~m}, 2 \mathrm{H}), 3.86(\mathrm{dd}, J=7.7,4.2 \mathrm{~Hz}, 1 \mathrm{H}), 3.72$ $(\mathrm{d}, J=8.0 \mathrm{~Hz}, 2 \mathrm{H}), 3.60(\mathrm{~s}, 1 \mathrm{H}), 2.15(\mathrm{dd}, J=12.7,8.8 \mathrm{~Hz}, 1 \mathrm{H})$, $1.99(\mathrm{dd}, J=12.8,7.4 \mathrm{~Hz}, 1 \mathrm{H}), 1.35-1.32(\mathrm{~m}, 15 \mathrm{H}), 1.30(\mathrm{~s}, 3 \mathrm{H})$; ${ }^{13}$ C NMR (DMSO- $\left.d_{6}\right) \delta 155.2,152.7,150.6,145.2,119.8,90.0$, 72.7, 70.9, 68.8, 65.3, 55.3, 30.1, 23.8, 19.5, 16.8; Analysis for $\mathrm{C}_{19} \mathrm{H}_{32} \mathrm{~N}_{5} \mathrm{O}_{6} \mathrm{P}$, Calcd.: C, 49.88; H, 7.05; N, 15.31; Found: $\mathrm{C}$, 49.84; H, 7.09; N, 15.37 .

(rel)-(1'R,2'S,3'S,4'S)-[9-(2,3,4-Trihydroxy-2,4-dimethylcyclopentyl)] adenine] methylphosphonic acid (20). To a solution of the phosphonate $\mathbf{1 8}(186 \mathrm{mg}, 0.408 \mathrm{mmol})$ in $\mathrm{CH}_{2} \mathrm{Cl}_{2}(14$ $\mathrm{mL}$ ) was added trimethylsilyl bromide (672 $\mathrm{mg}, 4.44 \mathrm{mmol})$. The mixture was heated under reflux for $20 \mathrm{~h}$ and then concentrated under reduced pressure. The residue was partitioned between $\mathrm{CH}_{2} \mathrm{Cl}_{2}(20 \mathrm{~mL})$ and distilled $\mathrm{H}_{2} \mathrm{O}(20 \mathrm{~mL})$. The aqueous layer was washed out with $\mathrm{CH}_{2} \mathrm{Cl}_{2}$ and then freeze-dried to give target compound 20 (125 mg, 82\%) as a yellowish foamy solid. mp $106-108{ }^{\circ} \mathrm{C} ;{ }^{1} \mathrm{H}$ NMR (DMSO- $\left.d_{6}, 300 \mathrm{MHz}\right) \delta 8.26(\mathrm{~s}, 1 \mathrm{H})$, 8.12 (s, 1H), 7.13 (br s, 2H), $5.13(\mathrm{~s}, 1 \mathrm{H}), 4.85$ (br s, 1H), 3.82 (d, $J=7.8 \mathrm{~Hz}, 1 \mathrm{H}), 3.72(\mathrm{~d}, J=8.1 \mathrm{~Hz}, 2 \mathrm{H}), 3.63(\mathrm{~s}, 1 \mathrm{H}), 2.14(\mathrm{dd}$, $J=12.7,8.6 \mathrm{~Hz}, 1 \mathrm{H}), 1.96(\mathrm{dd}, J=12.8,7.7 \mathrm{~Hz}, 1 \mathrm{H}), 1.33$ (s, $3 \mathrm{H}), 1.30(\mathrm{~s}, 3 \mathrm{H}) ;{ }^{13} \mathrm{C}$ NMR (DMSO-d $) \delta 154.9,152.0,150.2$, 145.5, 119.7, 88.9, 72.6, 69.6, 65.7, 54.0, 28.8, 20.1, 16.1; Analysis for $\mathrm{C}_{13} \mathrm{H}_{20} \mathrm{~N}_{5} \mathrm{O}_{6} \mathrm{P}\left(+2 \mathrm{H}_{2} \mathrm{O}\right)$, Calcd.: C, 38.14; H, 5.91; N, 17.11; Found: C, 38.07; H, 5.99; N, 17.08.

(rel)-(1'R,2'S,3'S,4'S)-Cyclic SATE phosphoester of [9-(4methyloxyphosphonate-2,3,4-trihydroxy-2,4-dimethylcyclopentyl)] adenine (22). A solution of adenine phosphonic acid derivative 20 (44 mg, $0.118 \mathrm{mmol})$ and tributylamine $(200 \mu \mathrm{L}$, $0.80 \mathrm{mmol})$ in water $(1.5 \mathrm{~mL})$ was mixed for $30 \mathrm{~min}$ and concentrated under reduced pressure. The residue was thoroughly dried with anhydrous ethanol and toluene. The resulting foamy solid was dissolved in anhydrous pyridine $(10 \mathrm{~mL})$ to which thioester 21 (180 mg, $1.1 \mathrm{mmol}$ ) and 1-mesitylene-2-sulfonyl3-nitro-1,2,4-triazole (148 mg, $0.5 \mathrm{mmol}$ ) were added. The mix- 
ture was stirred for $16 \mathrm{~h}$ at room temperature and quenched with tetrabutylammonium bicarbonate buffer $(5 \mathrm{~mL}, 1 \mathrm{M}$ solution, $\mathrm{pH}$ 8.0). The mixture was concentrated under reduced pressure and the residue was diluted with water $(50 \mathrm{~mL})$ and extracted twice with $\mathrm{CH}_{2} \mathrm{Cl}_{2}(50 \mathrm{~mL})$. The combined organic layer was washed with brine, dried over $\mathrm{MgSO}_{4}$, filtered, and evaporated. The residue was purified by silica gel column chromatography (MeOH/Hexane/EtOAc, 0.05:3:1) to give $22(16 \mathrm{mg}, 28 \%)$ as a solid: mp $113-115{ }^{\circ} \mathrm{C}$; UV $\left(\mathrm{H}_{2} \mathrm{O}\right) \lambda_{\max } 261.0 \mathrm{~nm} ;{ }^{1} \mathrm{H}$ NMR $\left(\mathrm{DMSO}-d_{6}, 300 \mathrm{MHz}\right) \delta 8.25(\mathrm{~s}, 1 \mathrm{H}), 8.12(\mathrm{~s}, 1 \mathrm{H}), 4.19(\mathrm{t}, J=$ $6.4 \mathrm{~Hz}, 2 \mathrm{H}), 3.70(\mathrm{~d}, J=8.2 \mathrm{~Hz}, 2 \mathrm{H}), 3.32(\mathrm{~s}, 1 \mathrm{H}), 3.24(\mathrm{t}, J=$ $6.3 \mathrm{~Hz}, 2 \mathrm{H}), 2.10(\mathrm{dd}, J=12.6,8.6 \mathrm{~Hz}, 1 \mathrm{H}), 1.91(\mathrm{dd}, J=12.6$, $7.2 \mathrm{~Hz}, 1 \mathrm{H}), 1.29(\mathrm{~s}, 3 \mathrm{H}), 1.21(\mathrm{~s}, 9 \mathrm{H}), 1.01(\mathrm{~s}, 3 \mathrm{H}) ;{ }^{13} \mathrm{C} \mathrm{NMR}$ $\left(\mathrm{DMSO}-d_{6}\right) \delta 202.4,154.7,151.8,150.5,145.7,119.5,94.4$, 70.6, 69.2, 67.4, 65.2, 54.3, 51.3, 33.2, 28.3, 24.2, 19.3, 15.3. Analysis for $\mathrm{C}_{20} \mathrm{H}_{30} \mathrm{~N}_{5} \mathrm{O}_{6} \mathrm{PS}(+0.5 \mathrm{MeOH})$ : C, 47.76; H, 6.26; N, 13.58; Found: C, 47.83; H, 6.19; N, 13.50.

Acknowledgments. This study was supported by research grant of Chosun University, 2010.

\section{References}

1. Choo, Q. L.; Kuo, G.; Weiner, A. J.; Overby, L. R.; Bradley, D. W.; Houghton, M. Science 1989, 244, 359.

2. Wu, J. Z.; Yao, N.; Walker, M.; Hong, Z. Mini. Rev. Med. Chem. 2005, 5, 1103-1112. (b) McHutchison, J. G.; Patel, K. Hepatology 2002, 36 suppl 45.

3. (a) Pawlotsky, J. M. Antiviral Res. 2003, 59, 1. (b) Fried, M. W. Hepatology 2002, 36, suppl 237.

4. Szabo, E.; Lotz, G.; Paska, C.; Kiss, A.; Schaff, Z. Pathol. Oncol. Res. 2003, 9, 215.

5. (a) Bera, S.; Malik, L.; Bhat, B.; Carroll, S. S.; MacCoss, M.; Olsen, D. B.; Tomassini, J. E.; Eldrup, A. B. Bioorg. Med. Chem. Lett. 2003, 13, 4455. (b) Clark, J. L.; Hollecker, L.; Mason, J. C.; Stuyver, L. J.; Tharnish, P. M.; Lostia, S.; McBrayer, T. R.; Schinazi, R. F.; Watanabe, K. A.; Otto, M. J.; Furman, P. A.; Stec, W. J.; Patterson, S. E.; Pankiewicz, K. W. J. Med. Chem. 2005, 48, 5504. (c) Smith, D. B.; Martin, J. A.; Klumpp, K.; Baker, S. J.; Blomgren, P.
A.; Devos, R.; Granycome, C.; Hang, J.; Hobbs, C. J.; Jiang, W. R.; Laxton, C.; Le Pogam, S.; Leveque, V.; Ma, H.; Maile, G.; Merrett, J. H.; Pichota, A.; Sarma, K.; Smith, M.; Swallow, S.; Symons, J.; Vesey, D.; Najera, I.; Cammack, N. Bioorg. Med. Chem. Lett. 2007, 17, 2570. (d) Li, H.; Baik, Y. C.; Hong, J. H. Bull. Korean Chem. Soc. 2009, 30, 1147. (e) Liu, L. J.; Kim, S. W.; Lee, W.; Hong, J. H. Bull. Korean Chem. Soc. 2009, 30, 2989.

6. (a) Rondla, R.; Coats, S. J.; McBrayer, T. R.; Grier, J.; Johns, M.; Tharnish, P. M.; Whitaker, T.; Zhou, L.; Schinzai, R. F. Antiviral Chem. Chemother. 2009, 20, 99. (b) Li, H.; Yoo, J. C.; Hong, J. H. Nucleosides, Nucleotides \& Nucleic Acids 2009, 28, 809. (c) Ko, O. H.; Hong, J. H. Nucleosides, Nucleotides \& Nucleic Acids 2009, 28, 761.

7. Eldrup, A. B.; Allerson, C. R.; Bennett, C. F.; Bera, S.; Bhat, B.; Bhat, N.; Bosserman, M. R.; Brooks, J.; Burlein, C.; Carrol, S. S.; Cook, P. D.; Getty, K. L.; MacCross, M.; McMasters, D. R.; Olsen, D. B.; Prakash, T. P.; Prhavc, M.; Song, Q. L.; Tomassini, J. E.; Xia, J. J. Med. Chem. 2004, 47, 2283.

8. Eldrup, A. B.; Prhavc, M.; Brooks, J.; Bhat, B.; Prakash, T. P.; Song, Q.; Bera, S.; Bhat, N.; Dande, P.; Cook, P. D.; Bennett, C. F.; Carroll, S. S.; Ball, R. G.; Bosserman, M.; Burlein, C.; Colwell, L. F.; Fay, J. F.; Flores, O. A.; Getty, K.; LaFemina, R. L.; Leone, J.; MacCoss, M.; McMasters, D. R.; Tomassini, J. E.; Von Langen, D.; Wolanski, B.; Olsen, D. B. J. Med. Chem. 2004, 47, 5284.

9. (a) Koh, Y. H.; Shim, J. H.; Wu, J. Z.; Zhong, W.; Hong, Z.; Giradet, J.-C. J. Med. Chem. 2005, 48, 2867. (b) Carrol, S. S.; Tomassini, J. E.; Bosserman, M.; Getty, K.; Stahlhut, M. W.; Eldrup, A. B.; Bhat, B.; Hall, D.; Simcoe, A. L.; LaFemina, R.; Rutkowski, C. A.; Wolanski, B.; Yang, Z.; Migliaccio, G.; De Francesco, R.; Kuo, L. C.; MacCross, M.; Olsen, D. B. J. Biol. Chem. 2003, $278,11979$.

10. Kim, C. U.; Luh, B. Y.; Martin, J. C. J. Org. Chem. 1991, 56, 2642.

11. Wu, T.; Froeyen, M.; Kempeneers, V.; Pannecouque, C.; Wang, J.; Busson, R.; De Clwecq, E.; Herdewijn, P. J. Am. Chem. Soc. 2005, 127,5056

12. Jeong, L. S.; Lee, J. A. Antiviral Chem. Chemother. 2004, 25, 235.

13. Iwasawa, N.; Kato, T.; Narasaka, K. Chem. Lett. 1988, 1721.

14. Trost, B. M.; Kuo, G. H.; Benneche, T. J. Am. Chem. Soc. 1988, 110,621 .

15. Périgaud, C.; Gosselin, G.; Lefebvre, I.; Girardet, J. L.; Benzaria, S.; Barber, I.; Imbach, J. L. Bioorg. Med. Chem. Lett. 1993, 3, 2521.

16. Shim, J.; Larson, G.; Lai, V.; Naim, S.; Wu, J. Z. Antiviral Res. 2003, 58, 243. 